\title{
Experiences in Regional Cross Border Co-operation in River Management. Comparing Three Cases at the Dutch-German Border
}

\author{
Mark Wiering • Joris Verwijmeren • Kris Lulofs • \\ Christian Feld
}

Received: 26 May 2009 / Accepted: 27 December 2009 /

Published online: 26 January 2010

(C) Springer Science+Business Media B.V. 2010

\begin{abstract}
Cross border co-operation is increasingly viewed as an obvious and logical consequence of an integrated perspective on river management. Consequently, we would expect an increase of cross border co-operation and collaboration in EU member states, through joint planning, co-management or co-implementation in flooding policies, water quality management or river rehabilitation. If we take a closer look at regional practices along member states' borders however, co-operation is often considered as problematic. To explain this discrepancy it is important to look at the conditions of 'successful' co-operation in actual cross border initiatives. We provide a framework to analyse regional initiatives, focusing on the extent of co-operation and differences and similarities in policy arrangements. We apply this framework to three cases at the Dutch-German border and conclude that the nature of the problem structure and related interdependencies and 'urgency' (still) are important. Moreover, we stress the importance of policy styles and especially the problematic transition from policy formulation to policy implementation in water management.
\end{abstract}

M. Wiering $(\bowtie)$

Department of Political Sciences of the Environment, Radboud University of Nijmegen,

Nijmegen, the Netherlands

e-mail: m.wiering@fm.ru.nl

J. Verwijmeren

Hospitality Business School, Saxion University of Applied Sciences, Deventer, the Netherlands

K. Lulofs

Centre for Clean Technology and Environmental Policy, University of Twente,

Enschede, the Netherlands

C. Feld

Institute of Biology - Applied Zoology/Hydrobiology, University of Duisburg-Essen,

Essen, Germany 
Keywords Cross border co-operation - Transboundary co-operation . River basin management - Water policy • Policy analysis - Policy arrangements . Water Framework Directive $\cdot$ Flooding management $\cdot$ River restoration

\section{Introduction}

Over the last decades contemporary water management is gradually, but inevitably evolving from fragmented, differentiated types of policy towards practises of integrated water resources management and integrated river basin management (Mostert 1998; Tucker Gilman et al. 2004; Watson 2004; Kuks 2004; Wiering and Crabbé 2006; Jaspers 2003; Van der Keur et al. 2008).

The river basin (or the total water catchment area of a river or drainage basin) is considered the basic unit for all planning and management actions. Although it has variously been defined (Barrow 1998; Tucker Gilman et al. 2004; Jones et al. 2003), it is increasingly being used as the overarching concept to point at integrated and interactive water policies. The concept of river basin management incorporates at least three integrative ambitions concerning water systems and policy making. Starting from the water system itself, 'from inside to outside', the first integrative ambition is to connect and combine different aspects of water systems, such as water quality and water quantity, groundwater and surface water, as well as relations in the water chain (internal water system-integration). Next, it stresses the need for external relationships between water management and other policy domains, such as spatial planning, agriculture, housing, nature conservation and tourism (sometimes referred to as external integration). Finally, it takes the river basin as starting point for administrative co-operation and, as such, is crossing administrative and geographical borders (aiming at cross border integration). In this line of reasoning, transboundary and interregional co-operation is increasingly viewed as an obvious and logical consequence of an integrated perspective on the management of the major rivers of Europe (Mostert 1998; Jones et al. 2003; Kuks 2004). This trend towards integration and co-operation between member states is empowered by major European directives in the field: the Water Framework Directive (WFD, Directive 2000/60/EC) and the European Flood Risk Directive (EFD, Directive on the assessment and management of flood risks; 2007/60/EC). ${ }^{1}$ Especially the WFD strongly affects both national and regional water policy practices. In the WFD 'river basin' means "the area of land from which all surface run-off flows through a sequence of streams, rivers and, possibly, lakes into the sea at a single river mouth, estuary or delta" (art 2, nr. 13). The Directive stresses international and cross border co-operation and harmonisation through different procedural steps towards river basin management plans (Kaika 2003; Meijerink and Wiering 2009). The European Flood Risk Directive is prescribing and stimulating cross border co-operation in warning systems and other elements of flood risk management.

\footnotetext{
${ }^{1}$ Although the fact we need two major directives for water management can also account for the lack of integration between flooding policies on the one hand and issues of water quality and ecology on the other.
} 
Consequently, an increase of cross border co-operation and collaboration between EU member states could be expected, for instance through joint planning, comanagement or co-implementation in flooding policies, water quality management as well as in river rehabilitation or restoration. Taking a closer look at regional policy practices along member states' borders, however, co-operation is often viewed as problematic. So, while 'Europe' is striving for a borderless river basin management, harsh realities reflected in regional practices do not always meet these demands. This is why the conditions of 'successful' co-operation in actual cross border river initiatives deserve more consideration. What exactly are the barriers and obstacles that sometimes make transboundary co-operation so difficult to achieve? And what are the incentives that encourage co-operation and collaboration?

These central questions lead us to focus on today's experiences of regional cross border river management. Next to this empirical focus, a theoretical framework is suggested that deals with divergent perspectives that explain the development of cross border co-operation. What are contemporary theories on cross border cooperation telling us about conditions of 'succesful' co-operation? And, can these elements be connected as part of a comprehensive framework to describe and explain how regional transboundary river management evolves?

In the following sections we first give a short overview of literature on water management in cross border settings (Section 2). This reveals explanatory variables and conditions of successful co-operation on the basis of existing literature. We link the principal explanatory variables to a specific perspective in policy analysis, that of the policy arrangements approach (PAA) (Section 3) and elaborate the way 'successes' of cross border co-operation initiatives can be assessed. Section 4 contains a short outline of the underlying empirical research. In the following sections the framework is applied to three cases on the border of Germany and the Netherlands. On the basis of our empirical findings we compare results of the cases in Section 8 and give our conclusions and reflections in the final section.

\section{Explaining Cross Border Co-operation: An Overview}

There are excellent overviews on the literature of cross border co-operation and international river management available (Bernauer 2002; Marty 2001; Lindemann 2006; Mostert 1998). Conditions of success and failure of cross border co-operation in water management have also been issued by many authors. Since it is impossible to discuss all findings of the rich and wide-ranging literature here, this overview is resticted to studies that in our view give complementary explanations for the dynamics of co-operation, and which are suitable and informative for an analysis in the European context, without pretending to be exhaustive (with special focus on Le Marquand 1977; Saetevik 1988; Dupont 1993; Meijerink 1998; Dieperink 1999, 2000; Linnerooth 1990; List 1990; Bressers and Kuks 2004; Marty 2001; Skjaerseth 2000; Haas 1990; Blatter 2001; Lindemann 2006).

Most scholars of cross border co-operation acknowledge that the general response of policy actors is at least in part dependent on the basic features of the problem or the problem structure. The principle is that co-operation is generally less likely in upstream-downstream situations than in situations "characterized by more symmetrically distributed environmental damages, most notably in the case of 
common pool resources (...)" (Bernauer 2002: 6). Upstream-down stream conditions often correspond to so-called dead lock games. To overcome these dead lock situations, the literature reveals three dominant approaches. The first major branche of literature is based on an analysis of negotiation processes in which key concepts are (policy-) actors, interests and resources. To overcome asymmetries in the problem structure policy actors will try to achieve their objectives by trade off's and/or making resources available for (upstream) partners, e.g. by financial means. A second group of authors shares a 'regime perspective' to analyze co-operation. The concept of 'regime' refers to the principles, norms, rules and procedures that implicitly or explicitly guide interactions between policy actors. A regime-approach points at the establishment of a set of cross border institutions that contribute to the solution of the water management problems. And recently the rise of a third approach in the literature on cross border co-operation in water politics can be witnessed. In this relatively new approach the focus shifts from the more organizational (policy actors, resources and institutional rules) dimension of policy making to its content; the ideas, the policy concepts in use, the belief systems or problem definitions of actors. These, what we call, cognitive and discursive approaches, stress that the extent of co-operation, as well as the direction in which it evolves, is strongly influenced by the frames and concepts that actors use to give meaning to the problems with which they are confronted. Below these three dominant approaches will be given some more detail.

\subsection{Negotiation Processes, Actors and Interests}

Authors that focus on negotiation processes generally define successful co-operation as a result of the distribution and redistribution of interests and resources on either side of the border (e.g. Le Marquand 1977; Saetevik 1988; Dieperink 1999, 2000). To establish co-operation "for each party the net satisfaction desired from international agreement must be greater than that associated with the national option" (e.g. Le Marquand 1977, p. 19). Co-operation is dependent on the complementarity of resources, possible exchanges and trade offs within the relevant policy domain. When trade offs within the domain are not possible or feasible, a solution might be found in the linkage of the relevant issue with issues outside the domain. So, for example, in the Scheldt river basin water quality and estuarine rehabilitation downstream were first linked to the issue of maritime acces to the port of Antwerp, an important interest of Belgium. In a later stage these issues were further linked to the Meuse river basin (at considerable geographically distance) and to discussions between The Netherlands and Belgium (Flanders) on the High Speed Train linkage (Linnerooth 1990; Meijerink 1998). Another condition that could help to overcome an adverse distribution of (water-related) interests and resources is the existence of a dominant actor (nation state), although many authors have doubts about the effectiveness (see Haas 1990 on the dominance of France; List 1990 on the USSR, and Lindemann 2006 on Germany as a dominant player in negotiations).

The analysis of negotiations also provides insight into other, additional factors that stimulate successful negotiation and co-operation: is sufficient knowledge available? What about the quality of the delegations and of the supportive secretariat? And are particular actors involved, most notably politicians? 


\subsection{Regime Approach}

The nature of asymmetries and interdependencies, and the related distribution of interests and resources is generally recognized as highly relevant, but they do not always explain the establishment of successful cross border co-operation. The regime approach shifts the focus to the nature of the institutions that are created to foster and entrench co-operation. Young (1999) defined regimes nicely and openly as "recognised patterns of practice around which expectations converge". Regimes have both a substantial dimension, seen as rights, norms and rules, and a more procedural dimension, that of recognized arrangements for social and collective choices. Different authors were inspired by this approach that fits international arrangements and agreements (more in Young 1999; Kahler et al. 1995; Keohane and Nye 1989; Marty 2001; Ma et al. 2008). Summing up some of the findings of regime theory (Marty 2001; Skjaerseth 2000): cross border co-operation is more easily established when procedures for decision making encourage clarity about the objectives of the actors involved, when they are flexible enough to cope with changing circumstances, and when they are based on majority voting. The implementation of joint regulation, in later stages of the policy process, will be more successful when these commitments are binding, clear, transparent and feasible. According to Skjaerseth (2000) international regimes mostly should produce common norms and values; they can and should encourage the aggregation and integration of the interests of the countries or riparian states involved. Both Marty and Skjaerseth stress however, that institutions (as regimes) can not be implanted; they evolve slowly and are historically contingent.

\subsection{The Importance of Discourse}

A third approach focuses more on discursive and cognitive processes. Authors with this perspective want to discover which beliefs are held by the policy making actors, where shared beliefs become important and how they stimulate or hamper joint policy making (e.g. Haas 1990; Blatter 2001; Meijerink 2008). Haas (1990) looked at co-operation regarding environmental pollution of the Mediterranean Sea and the formation of the so-called MedPlan. Haas first considered the more traditional explanatory frameworks of neo-realism and historical materialism. He concluded that the distribution of power among countries or the influence of the more dominant country in the region (France) could not explain the developments in co-operation. The rise of a transnational alliance of scientists offered a better explanation. This so-called transnational epistemic community shared common knowledge about environmental pollution, but also common beliefs and objectives that were institutionalized in new governmental and intergovernmental institutions and 'penetratred' policy making in this way. Blatter (2001) observed that in the case of regulating the pollution caused by motor boats on the transboundary Lake Constance, cross border co-operation evolved around an issue where co-operation was not obviously following from interdependencies or the distribution of interests and objectives of the co-operating countries, and where the relevant damage could readily be assigned to a specific jurisdiction. Instead, Blatter focuses on discursive elements of co-operation. In line with Haas, the problem of lake Constance was put forward by a coalition 
of environmental protectionists and the case of pollution of motor (pleasure) boats offered the existing political cross border institutions a platform of high symbolic value which could be used to emphasise the importance of their own existence (see Verwijmeren and Wiering 2007, p. 32). Secondly, Blatter relates the extent of cross border co-operation to the trends in integrational discourses in Europe, that vary with the momentum of signing specific important Treaties or other focusing events. Thus, he shows the importance of investigating not only interests, resources and rules, but also general discourses, both material or substantial discourses connected to the issue involved as well as to the co-operation itself.

In short, this perspective puts forward that co-operation is more easily established when the problem at hand is framed as a joint problem, when the problem and/or its solution are perceived in similar terms by all actors, when an epistemic community of professionals and a general overall discourse (e.g. 'ecology') exists that either encourages solving the problem at hand or encourages cross border co-operation in general.

\subsection{The Role of the Macro-context}

All explanatory or 'independent' variables discussed so far mainly focus on the nature of the problems, the circumstances and features of initiatives and institutions at the cross border level itself. Some authors however, take the macro-context of cross border co-operation into account and stress the influence of national policy making and politics. List (1990), for example, explains how the West German Ostpolitik (politics towards eastern Europe) paved the way for co-operation in the Baltic Sea. Two authors have actually elaborated this type of analysis. Marty (2001) analyses the effects of national negotiations, concluding that the absence of involvement of national authorities may seriously hamper the establishment of co-operation at a regional level. Skjaerseth (2000) analyses the effects of national institutions, explaining that a high level of integration within national governments as well as a national preference for command and control policy tools will positively influence the actual implementation of cross border regulation.

On the issue of integration of countries, Bernauer (2002) refers to the work of Rainer Durth: “(...) problems are easier to solve if riparian countries are more integrated, i.e. when the density of political, economic and societal ties among countries is greater." Bernauer summarises the arguments of Durth; with more integration, compensation of upstream countries is easier, countries will make more credible commitments to one another, information is more complete (and transparent), notions of equity or justice are likely to be congruent, transboundary institutions (that are more likely to develop too) can mitigate unequal bargaining leverage and finally, opportunities for non-governmental players to influence outcomes are greater (Bernauer 2002: 7; see also Durth 1996).

Dupont (1993) also points at cultural differences or similarities. Dupont investigated co-operation of the river basin states of the Rhine and the International Commission of Protection of the Rhine in a specific period of time. He found that countries increasingly came to regard water pollution as a shared problem that was their joint responsibility. As a result they were able to reach an agreement despite the great differences in socioeconomic interests. Dupont concludes that the (relatively) 
homogeneous cultural background of the countries in the Rhine river basin helped negotiators conduct negotiations in a more constructive way.

\subsection{An Integrated Approach}

The overview above confirms that a great deal of knowledge already exists about the determinants of succesful cross-border co-operation; one may even wonder why additional research was necessary. Each of these approaches has its own pros and cons. However, to get a thorough understanding of cross-border co-operation it is useful to combine these different approaches and perspectives towards a more integrated and comprehensive approach, which gives room for the different dimensions mentioned: actors, resources, institutional rules, and discourse. And these aspects can be assessed on both a micro level (regional arrangements) and macro level (national arrangements). Below we wil discuss such an approach: the so called Policy Arrangements Approach.

\section{Elaborating the Analytical Framework}

Why do some regions or countries go further down the road of transboundary cooperation and others have a hard time achieving any results? First, we return to a basic explanation, in that it depends on features of the problem itself (problem structure) and the related basic distribution of interests (see Section 2). For river basin management in general holds that the upstream and downstream-geography often influences the distribution of interests and resources of countries in the river basin. Downstream countries will be more interested in co-operation in water quality or flooding issues, and upstream countries when navigation issues are at stake (e.g. when a downstream harbor or issues of access to water resources are involved; see Meijerink 1998).

Besides this rather straightforward explanatory framework, the differences and similarities of the institutions on either side of the border are of major importance. It goes without saying that co-operation is more easily established when differences between countries are small; this can be further specified by looking at the differences and similarities of (sectoral) policy arrangements, in other words, the congruence of institutions in policy domains on both sides of the border. Therefore, we make use of the so called Policy Arrangements Approach (PAA), that has been applied in several studies related to the environmental policy domain and water management (e.g. Van Tatenhove et al. 2000; Arts and Leroy 2006; Wiering and Arts 2006; Crabbe 2008). A policy arrangement is an analytical concept to describe and analyze the processes and outcomes of institutionalization in a specific policy domain. The approach pays attention to both institutional (as 'organisational') and discursive aspects of policymaking. A policy arrangement is initially described as "the temporary stabilization of the substance and organisation of a policy domain" and points at stability and change in policy processes (Van Tatenhove et al. 2000). It builds on four dimensions of policy: the actors involved (and their coalitions and interactions), the resources of actors, the rules of the game in the playing field of the policy domain and the relevant policy discourses. This approach is useful to include- and combine-varying 
explanatory variables found in literature. The policies along the different dimensions of a policy domain can be described; the role of policy actors and coalitions; the role of interest and (exchange of) resources; the role of formal and informal rules of the (co-operation) game; and finally the sector-based policy discourses as reflected by subject-related policy concepts, cultural traditions, storylines in policy argumentations, etc. With a description of policy arrangements identification of the main differences and similarities between the relevant water policies in the specific cross border region is possible, and, in addition, the enabling and constraining characteristics of the national arrangements (for more details see Verwijmeren and Wiering 2007). Finally, besides problem features and congruence of regional arrangements, a third explanatory variable is added to the conceptual model: the stand towards cross border co-operation of the national institutions or policies, which is of major importance for the policy discretion of regional arrangements.

The main purpose of this article is to explain the degree of actual co-operation in river management in cross border settings. To do this it is helpful to be as clear as possible about what is meant by the degree or extent of co-operation. Therefore three criteria will be used: co-operation formation, co-operation effectiveness and stakeholder satisfaction. Co-operation formation refers to the institutionalization of any co-operation initiative. It resembles the concept of regime formation (see e.g. Linnerooth 1990; List 1990). In general, it points to processes of structuring the 'ways of doing' or 'ways of thinking' across borders towards co-operative patterns. In actual practices, this can vary from opening up communication channels, discussing joint problem definitions to creating joint legislation or even organizations. The level of co-operation formation can be determined by looking at 'output': the amount and frequency of interactions, the scope and amount of joint research reports, policy documents, agreements, treaties, etc. Co-operation effectiveness is a thougher one. It is difficult to establish the exact causal links between cooperative activities and problem solving capacities in water management (but one generally presumes it helps). As an alternative to measuring causality in problem solving, one can look at the degree of implementation of specific ideas, plans, measures etc. in the policy practices, in other words the degree of adoption of institutions (e.g. policy concepts, -plans, -organizations) or institutional innovations.

The third criterion of 'successful' cross border co-operation is that of stakeholder satisfaction; it refers to the opinions of the actors involved about the degree of success of co-operation. This can, of course, only be an additional factor, but it is not unimportant because the ideas of involved parties on both side of the border can be taken into account, and third party-actors, such as NGO's or business, can be asked to reflect on the joint activities of governmental institutions.

\section{Outline of the Empirical Research}

The research project where our findings in this section stem from, took place within the framework of the so-called 'Rivercross'-project, which was funded by the Interreg IIIc programme Change on Borders. The project gave an opportunity to compare cross-border co-operation in different parts of Europe and, in the case of the Dutch-German border area, in different problem situations in the same border area. 


\subsection{Methodology}

At the start of the project a framework of analysis was set up. It consisted of three major parts: (1) giving a description of (the extent of) cross-border co-operation as the 'variable' to be explained, (2) giving a description of the regional policy arrangements involved to explain possible relevant differences and similarities, and (3) combine the two and give a rich explanation of the backgrounds of successful cross-border co-operation. Although some detailing and operationalisation turned out to be necessary during the project, this part of the analysis was implemented as devised.

There were different rounds of analysis in the project: a first round contained a structured questionnaire for the co-operating experts to apprehend the cross-border co-operation in each region and to select a limited number of projects for the case studies. During the following rounds each researcher described the selected projects with increasing levels of detail (in position and a framework papers, a situation report, and finally a chapter in an edited volume that contained the case studies and the project conclusions; Verwijmeren and Wiering 2007). Data collection consisted of desk study of literature and policy documents as well as interviews with five-seven stakeholders for every case study. Additionally, workshops were organised in which conclusions were discussed with stakeholders and experts alike.

The framework (Fig. 1) was applied to in total five cases of cross border cooperation in Europe. For the purpose of this article three cases on the DutchGerman border, dealing with three different issues in water management, are

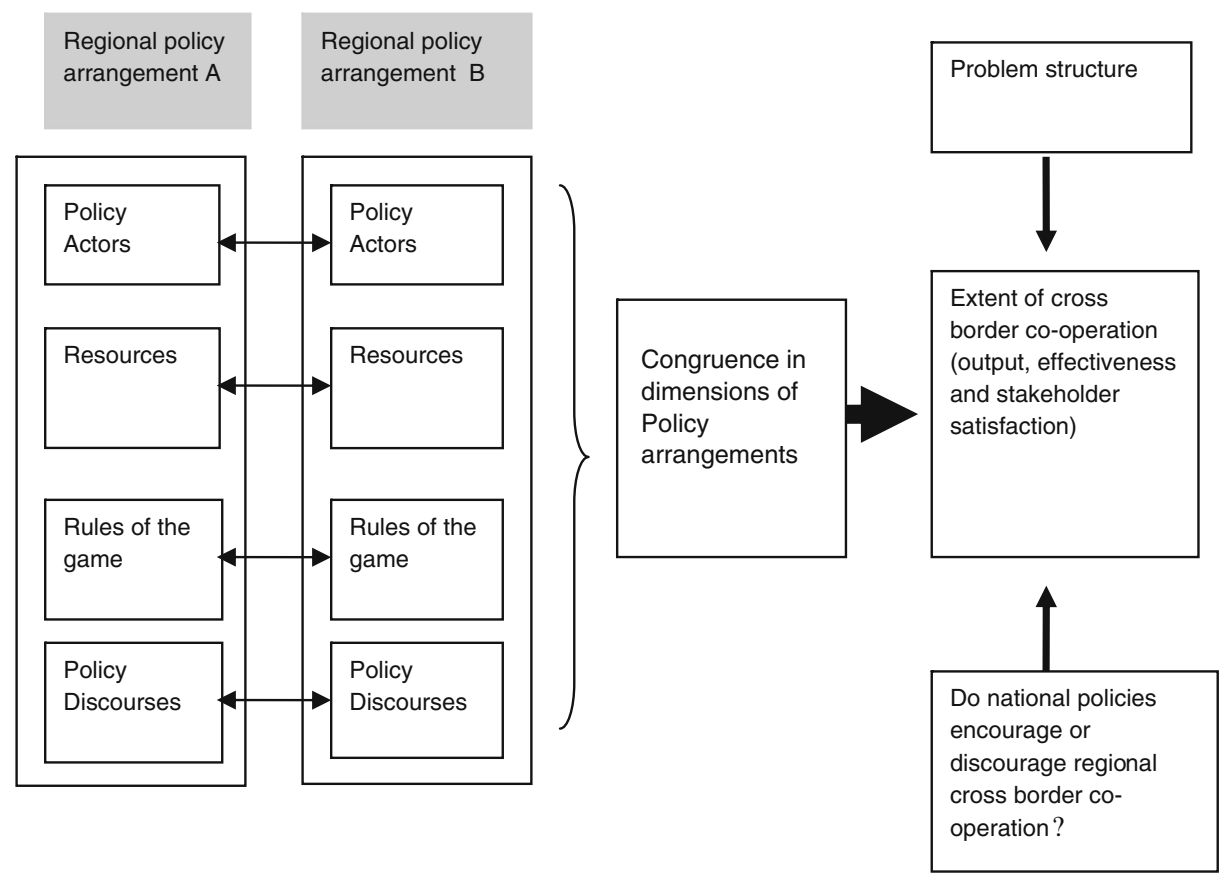

Fig. 1 A policy arrangement approach to cross border settings 
elaborated. The first case concerns river restoration. Dutch and German actors have been working together on the subject of river restoration for many years already in the sub-catchment of river Dinkel. The second case refers to water quality issues at the river Vechte/Vecht. The case describes and explains the Dutch-German cooperation while implementing the EU-Water Framework Directive. The third case addresses flood risk management policies along the river Rhine, especially the socalled Dutch-German Working Group on High Water.

The national background in general, e.g. national cultural features or political frameworks are similar (they all deal with Dutch and German policies) and they all have to some extent an upstream-downstream problem structure. But cases are different regarding the specific issue-related policy context and the arrangements that institutionalized around the topics addressed. Therefore, the focus shifted towards regional policies and arrangements.

Apart from the three cases mentioned above the research project also examined co-operation in flood protection along the Bug river in the Polish-UkrainianBelarussian border area and in the Evros Delta in the Greek-Bulgarian-Turkish border area. These cases are not discussed here because of the large contextual difference with the Dutch-German border area, e.g. as regards the degree of integration of countries. The interested reader will find more information in Verwijmeren and Wiering (2007) to see how was dealt with the other cases.

\section{The Dinkel Planning}

This section addresses cross border co-operation in the context of river restoration and is related partly to the EU WFD. In contrast to the case in the next section, however, German-Dutch co-operation in river restoration issues is not solely affected by the WFD and dates back well before the WFD was launched in 2000.

\subsection{Problem Structure}

River regulation, floodplain cultivation, and hydrological barriers, such as weirs and dams, have generated uniform rivers in Germany and the Netherlands, which no longer provide the capacity to fulfill their inherent functions (see Feld and LockerGrutjen 2007 for more detail). Consequently, hydro-morphological degradation of rivers and floodplains is considered a major problem in both countries. To overcome this problem, the German Federal State of North Rhine-Westphalia (NRW) established a Floodplain Protection Programme NRW to improve and sustain the natural development and dynamics of rivers and their floodplains. The programme provided the framework for other activities, such as the Floodplain Protection Concept River Ems (Darschnik et al. 1992; Staatliches Umweltamt Münster 1999, 2006), the Floodplain Concepts for the river Niers and the river Berkel (Bezirksregierung Münster 1999). Independently, and primarily driven by the major policy discourse of 'Room for the river' or 'Space for Water' in Dutch water policy (Van Stokkom et al. 2005; Wiering and Arts 2006) similar concepts have been set up in the Netherlands (e.g., 'The Dinkel and the Dinkel Valley', http://www.wrd.nl; 'Integrated Restoration of the Berkel', http://www.berkelproject.nl). 
Fig. 2 Map river Dinkel

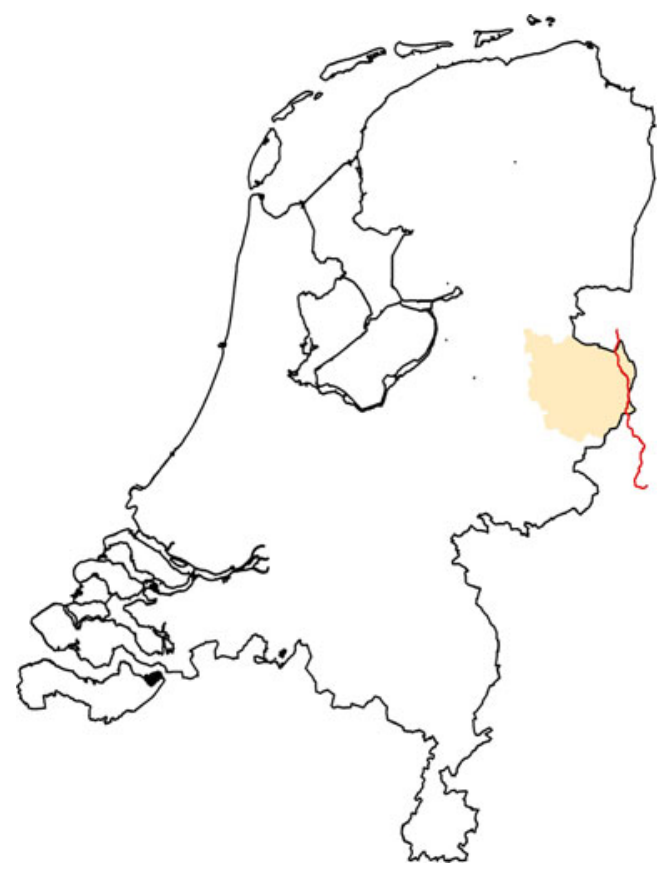

\subsection{Co-operation}

Although the cross border river Berkel was subject of restoration planning in both countries, the German 'Berkel Floodplain Concept' and the Dutch 'Integrated Restoration of the Berkel' were isolated initiatives at the same river. An example of more far-reaching coordination in the field of river restoration is the 'cross border Dinkel Planning' (Bezirksregierung Münster and Waterschap Regge en Dinkel 2003). The planning (hereafter referred to as Dinkel Planning) was jointly developed by German and Dutch project partners and partly funded within the INTERREG II program. The Dinkel is a major tributary to the Vecht $(e)$ and is $93 \mathrm{~km}$ long. It drains an overall catchment of $650 \mathrm{~km}^{2}$ (Bezirksregierung Münster and Waterschap Regge en Dinkel 2003). The entire river course has been hydro-morphologically degraded, natural dynamics are largely lacking due to water regulation and flood protection measures, while the water quality is impacted by nutrient and pesticides due to intensive agricultural land use in the catchment (Fig. 2).

From 1997-2001, the partners jointly made an inventory of the morphological status of the entire river course and its adjacent floodplains. The inventory aimed at facilitating future floodplain restoration and conservation planning, and ultimately at improving the overall river ecosystem quality and dynamics. Remarkably, the fairly progressive cross border collaboration has already been in line with the aims and scope of the WFD long before 2000.

\subsection{Co-operation Effectiveness}

A project steering group member responded in an interview that the Dinkel Planning itself can be seen as a success: "The planning provided-for the first time-a cross 
border co-operation aiming at the restoration of an entire river and its floodplain". Although other respondents generally agreed with this statement, stakeholder responses start to differ, when it comes to the implementation of the planning: the implementation is still hampered by manifold obstacles. The question of land use changes, private property rights to floodplains or areas on the floodplain, and possible adverse economic effects of restoration measures are still open. Integrated river restoration, i.e. restoration that extends from the river into the floodplain, will be impossible if the land owners (primarily farmers) refuse to sell or make their land on the floodplain available for restoration schemes. "Basically, the situation is demoralizing, as there is no way to implement the Dinkel Planning. We will have to get every single part of it through an exhaustive official planning and approval process, which is simply impossible", a respondent stated, visibly annoyed by the situation. Thus, stakeholder satisfaction gives a mixed picture when regarding both policy formulation and implementation.

Within the four-year project, the Dinkel planning yielded three unpublished reports (one cross border report and two national ones), a summary and a bilingual brochure (Bezirksregierung Münster and Waterschap Regge en Dinkel 2003). Compared to the output of other cross border initiatives, the number of documents produced is large. Yet, the Dinkel Planning clearly shows that effectiveness cannot be solely and reliably assessed on the basis of document output.

\subsection{The Policy Arrangements Framework}

\subsubsection{Actors and Coalitions}

In both countries river restoration is mainly a regional policy field, within which two administrative pairs play the major role: the Dutch Provinces vs. District Governments in North Rhine-Westphalia and Dutch Water Boards vs. Regional Environmental Agencies in North Rhine-Westphalia. National/federal authorities are important actors too, as they provide legal or semi-legal frameworks for regional authorities, while local authorities become important during the implementation of specific restoration measures. From a policy actors' point of view, the cross border Dinkel Planning at first sight represents a good example of cross border co-operation in river restoration. The cross border consortium included regional representatives of the German-Dutch Border Waters Commission, Dutch Provinces and Water Boards, German District Governments and Regional Environmental Agencies, and two planning enterprises (see Feld and Locker-Grutjen 2007, p. 54, for details). In particular, the Dutch and German administrative pairs (see above) seem to 'fit' and work well together on the regional scale, although some political structures are different in both countries-there's, for instance, no counterpart for German Federal States in the Netherlands.

\subsubsection{Resources}

The amount of resources in the Dinkel Planning is considerable, as both money (project budget) and expertise were available with the actors involved. Besides cofinancing, the responsible authorities 'solely' had to co-ordinate the progress of the project, which was done extensively during numerous informal and formal meetings and oral and e-mail contacts. 


\subsubsection{Rules of the Game}

The Dinkel Planning did develop specific informal rules of the game. During the interviews with actors, two respondents stressed the rather informal character of the initiative. One respondent stated that he had fortnightly contacts during the planning phase (1998-2001). The coordination of project planners and coordinators was clearly structured, while the regional authorities (Bezirksregierung, province) provided the legal power to take decisions. Accordingly, the planning provided prerequisites for an efficient and successful policy initiative. It should be born in mind, though, that the Dinkel Planning did not aim at implementation, but solely at the planning of restoration schemes on the Dinkel floodplain. Thus, co-operation was possible on a more abstract level without being overly limited by existing spatial planning laws. Any implementation of the planning-even if intended very locally-would require much more effort and would bring many more rules into the game, one of which was the German approval of plans (Planfeststellung). This planning approval involves all stakeholders affected by the planning and often hinders and delays implementation. So 'real' success of the Dinkel Planning, i.e. the implementation of restoration schemes on the Dinkel floodplain, is hardly visible at present.

\subsubsection{Discourses}

There was no discourse that was specific for the Dinkel Planning. Rather, the planning fits almost perfectly into the general 'room for the river(s)' water policy concept. This is one of the major discourses at present in Germany and the Netherlands. In North Rhine-Westphalia, floodplain restoration has been an integral part of river restoration for more than 15 years. The major objective of this programme is to restore a natural river landscape, with its functions. In the Netherlands, 'room for the rivers', although also linked to the floodplains, predominantly means 'retention room for floods'. Being extensively threatened by flooding and thus increasingly sensitive to flooding problems, the Netherlands aims at creating flood retention capacities within a whole river basin. The rationale of the Dinkel Planning involves both motivations, and thus possible dissimilarities in discourses seem not to be major obstacles for co-ooperation.

Wrapping up, in principle there were no obstacles created by important differences in the nature of the policy arrangements on both sides of the border, looking at actors' constellation, resources available and joint discourses. The fundamental problem for the assessment of cross border co-operation though is that planning and implementation are two completely different processes. The Dinkel Planning initially did not aim at the implementation of restoration schemes. Instead, the aim was to compile the current status and conditions on the Dinkel floodplain, namely land uses, and to identify key areas for future restoration measures. The purpose was to create a shared vision on the Dinkel, setting down the Leitbild (reference or natural condition) for the Dinkel floodplains as a valuable and important step towards the restoration of the river and its floodplains. Hence, feasibility did not play an important role in the Dinkel Planning.

When the initiative is assessed in the light of implementation purposes and adoption of policy ideas (part of co-operation effectiveness), the same features can be interpreted as drawbacks, as is the lack of involvement of farmers in the 
planning. The need for river restoration is still obvious, especially considering the ecological ambitions of the Water Framework Directive, as is the need for a new discussion of future agri-environmental schemes. However, the Dinkel planning can only become reality as soon as major stakeholders and the general public accept the need for extensive river restoration and support large-scale (cross-border) restoration schemes.

To conclude this first case, river restoration is not a policy field that suffers from a strong urgency to create cross border policies. Traditionally, river restoration is predominantly a regional or even local endeavor. The low level of interdependence on the subject of river restoration does not urge politicians or the public to get involved. The Dinkel Planning was one of the most ambitious projects in creating joint planning but remained mostly a research project.

\section{The River Vecht and the Water Framework Directive}

In this section cross border co-operation is assessed in view of the implementation of the European Water Framework Directive (WFD) in Germany and the Netherlands.

\subsection{Problem Structure}

The WFD requires improvements in water quality with the objective of a good ecological and chemical status of all water bodies in Europe, to be reached in 2015 (first deadline). The Directive prescribes several procedures, work packages to be undertaken and products to be delivered. Major subsequent work packages concern the ecological characterization of the river basin, the development of a surface water quality monitoring system, the preparation of a program for improvement and finally the development of a river basin management plan. This analysis covers the characterization report and the monitoring system. If the (sub-) river basin crosses national borders, cross-border coordination is asked for. Our case is the river Vecht, that originates in the German federal state North Rhine Westphalia (NRW), streams through Lower Saxony and then enters into the Netherlands (cf. Lulofs and Coenen 2007). It is part of the WFD-district of Rhine-East, that is marked as a transboundary river basin district. Especially where water quality issues are concerned there are typically 'upstream-downstream'-interdependencies between Germany and the Netherlands (Fig. 3).

\subsection{Co-operation}

The preparation of the river basin characterization report in the two federal German states (North Rhine Westphalia and Lower Saxony) and for Dutch territory was out of phase and the approach and concepts varied substantially. The involved water managers acted relative autonomously and coordination was thus far from effective. This resulted in three reports that were dissimilar and heterogeneous and hard to integrate into the required format. When time was running out, the sub-reports were integrated pragmatically by a consultant. Afterwards many corrections were needed. Some blame the differences in the 'learning curve' of actors across borders and others think that national regimes and problem perceptions were more dominant. 
Fig. 3 Map river Vecht

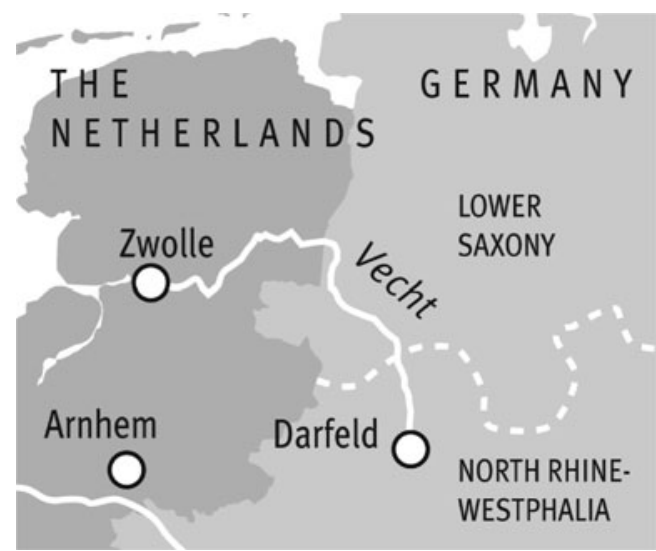

Subsequently the WFD asked for a monitoring system that included chemical and biotic indicators. A working group of Dutch and German water managers addressed this issue for the relevant area. A Dutch and two dissimilar German federal guidelines for monitoring already pre-existed and had to be harmonised somehow. The working group discussed the differences and possibilities for crossborder calibration. To create completely identical systems proved impracticable due to the impact of German federal requirements. But calibrating the systems was possible and now German and Dutch data can be converted. This enables upstream water managers interpret downstream data in their own system and reversed.

\subsection{Extent of Co-operation}

The criteria as introduced in Section 3 are now adressed. With regard to stake-holder satisfaction the interviewees expressed themselves in positive terms. The Dutch were pleasantly surprised by the cooperative attitude of the German upstream actors. German actors just acted 'corresponding to their policy style' that includes precise handling of hierarchical and legislative requirements. This implied that the EU initiated legally imposed WFD tasks were executed precise, but this accounts also for less immediate or pressing elements such as the coordination with the Dutch.

In terms of co-operation output success has to be judged as easily observable however sub-optimal. The obligatory output was realized, however the emerged coordination flaws with regard to content and quality should be kept in mind. Facilitating cross-border convertible monitoring data is a step towards more clarity for upstream-downstream coordination of surface water quality policy. Whether this will facilitate a program and a river basin management plan that will actual improve water quality depends on cooperation in coming years.

With regard to success measured in terms of co-operation formation, one has to conclude that the institutional sediment of cross border linkages is minimal. Furthermore the topics dealt with and products reflect just the minimal requirements as set by WFD. Actors explained that real integration appealed to them however the short term obligations of WFD required all available resources. Under these challenging circumstances the emphasis was more on securing national compliance with ambitious obligations and less on cross border coordination that was seen as 
extra-special. In this setting international coordination was still considered an addon element to national trajectories of WFD implementation.

\subsection{Policy Arrangements Framework}

Although this case is strongly influenced by the obligatory character of the WFD and water managers' fear of incompliance, some questions emerge. For instance why did actors not coordinate cross-border activities more timely and why were national water management traditions dominant in cross border interaction? The suspects in this article are singularities and differenced in elements of involved policy arrangements. The findings can be summarized as follows.

\subsubsection{Actors and Coalitions}

The in- and exclusion of actors proved influential. The number of actors involved in water management in Germany is larger and offers a less homogeneous landscape with regard to composition, tasks, responsibilities and legal position compared to the Dutch. Especially striking is the strong separation between actors involved in water policy making and actors involved in implementation. It is clear that German implementers hardly participated in the cross-border component of the activities. Some think that policy making and especially a high level of ambition gets easy by this, however it might boomerang back during implementation while implementers might lack finances and might prove not supportive of the policy. The involved Dutch actors are responsible for both policy making and implementation. Awareness of involved implementation costs and stakeholders, for instance farmers, to be encountered, led to a pragmatic approach.

\subsubsection{Resources}

For the described WFD activities limited financial resources were needed. Monitoring is not costly compared to the costs of taking pollution reduction measures. For other WFD activities costs might be substantial and the allocation of involved costs between upstream and downstream water managers might become an issue in the future. In Lower Saxony and North Rhine Westphalia the emphasis was on technical and expert knowledge. Exaggerated, this can be considered as an emphasis on an 'epistemic resource', emphasizing knowledge, science and exhaustive analysis. The Dutch reciprocity between, on the one hand, technical and expert resources and political and societal support as a resource on the other hand, extends more pragmatic and restrictive approaches to the knowledge domain.

\subsubsection{Rules of the Game}

The German administrative culture tends to be rather hierarchical, formal and legislative in comparison to the Dutch administrative culture. The German policy culture also includes a strong position for professional expert views and exhaustive analysis. Dutch political culture tends to be rather informal and horizontal. In water management the hierarchy between central government and de-central governments only exist in matters of 'national importance', and even then a consensual policy style is preferred. With regard to policy priorities the German actors often experience the 
Dutch positions as not stable and too pluralist. This led to confusion with regard to meetings and decisions. In some cases Germans perceived decisions to be taken while Dutch partners perceived the issues involved as a trial and error process, a strategy to bridge the pluralist landscape of technocrat and expert domains and political domestic domains. Dutch actors do not understand why they have to pass German superiors before they can confer with German colleagues.

\subsubsection{Discourses}

With regard to discourses related to water quality, there is an ongoing discourse on the quality of waste water treatment between Dutch and German authorities; the Dutch claim that German treatment infrastructure and plants function less effective. On the other hand, there is an ongoing debate that implies that German agriculture is less intensive and rinse off of German agricultural land is better regulated. So this implies the suggestion, from the German point of view, that if anyone has to improve their performances and decrease their waste load, the Dutch agricultural sector should do so' and one should not require such from the Germans. However, these discourses did not play a traceable role in the assessed WFD activities. This is not surprising, since it is only the subsequent phase, that of programming measures, that will upset and mobilize stakeholders.

Drawing conclusions from this case on the monitoring activities in the light of an European Directive, a "cooperative attitude" could be found, but co-operation activities were actually slow, fragmented and evolved only gradually despite generally resembling water policies in Germany and The Netherland, and despite the 'shadow of Europe'. The cause of this is again sought in a differentiating between policy formulation and policy implementation, but this time it is about the differences in administrative style in Germany and The Netherlands: the Dutch combinepolicy formulation and implementation and can switch between them, while German implementers are hardly involved in early phases of policy making. Similar remarks were made on the rules of decision making and the differences in the position of the expert. Discourses show several points of discussion on water quality, including a more or less a concealed distrust in activities across the border.

\section{The Dutch-German Working Group in the Rhine River Basin}

The Working Group on high water in the river Rhine area is the final DutchGerman case. The initiative to establish a Dutch-German Working Group came from the Dutch province of Gelderland (in the Eastern part of the Netherlands) in the mid-1990s. As one respondent put it, "The existing initiatives were too bureaucratic, focused too much on water quality and did not pay much attention to implementation. Besides, we felt that existing initiatives were at state-level and regional co-operation was lacking." (Verwijmeren and Wiering 2007 p. 96). The province of Gelderland contacted the German state of North Rhine-Westphalia in order to establish some form of co-operation in flooding politics in their border area. Together with a regional office of Rijkswaterstaat, the Inspectorate-General of the Transport and Water management, they became the lead participants in the DutchGerman Working Group on high water. 


\subsection{Problem Structure}

The problems with flooding were felt most urgently when two flood events in the Rhine area occured, one in 1993 and one in 1995. The 1995-event was most delicate in the Rhine area, not because of a real disaster, but because of the threat of disaster that created shock waves in Dutch society, as dikes were only just keeping the water from crossing the top and there was serious danger of dike-bursts because of the quality of dikes. About 250,000 people were evacuated in the Dutch part of the basin. After this 'warning sign' Dutch-German co-operation increased, also within the framework of the International Commission for the Protection of the Rhine. But, as was stated above, the bilateral contacts on a national level and the formal consultations and co-operation were not satisfactory; the regions felt the urge of closer co-operation on the regional level. The flooding issue is both a classical assymetrical 'upstreamdownstream' problem but contains more symmetrical elements too, because flood measures taking downstream can have a limited, but substantial impact upstream or are of importance for the region as a whole. Moreover, protecting polders from flooding and regulating the water household in the whole regional area are clearly featured by cross border mutual interdependencies (Fig. 4).

\subsection{Co-operation}

The Working Group has mainly worked on joint research projects, e.g. on extreme levels of high water in the upper Rhine area (Lammersen 2004), and cross border risk

Fig. 4 Map Rhine river basin

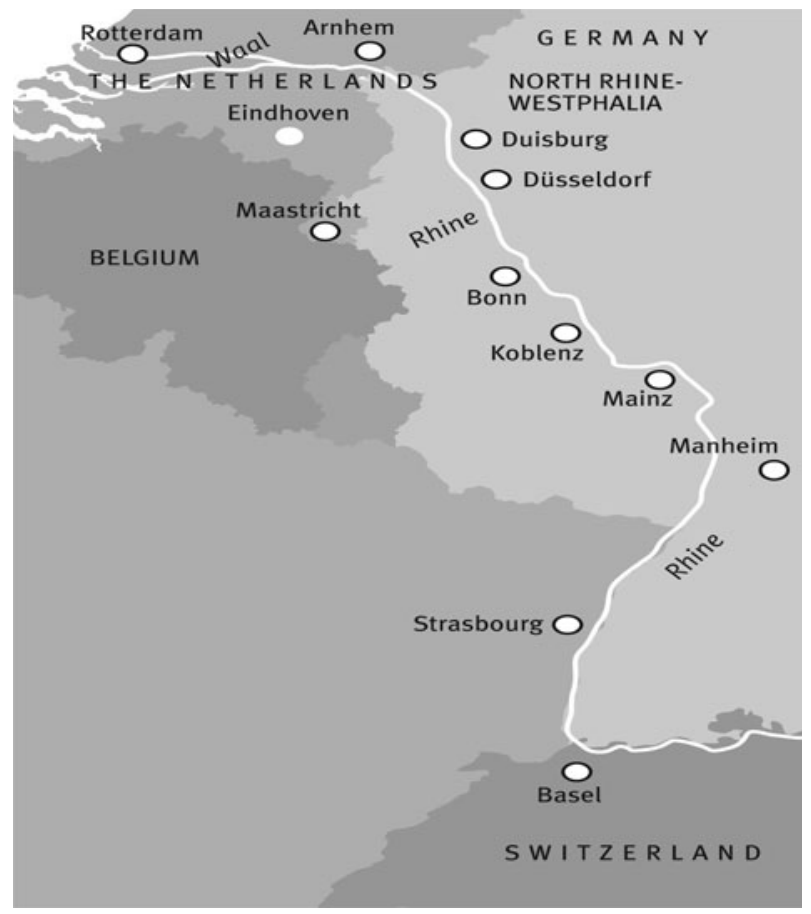


analysis, but also takes effort in informing the (national and regional) public about Dutch-German cross border water issues. It publishes a yearly bilingual magazine on flooding issues and organizes a biennial conference. Until now the Working Group has not worked on actual joint policy planning, policy- or project activities, although there are closely related projects that deal with developing flood warning systems (the VIKING project) and cross border inspections of flood defenses.

\subsection{Extent of Co-operation}

As far as co-operation formation and output is concerned, the Working Group can be considered an example of successful cross border co-operation. Co-operation in the Working Group is based on a 'common declaration', which constitutes the 'formal rules of the game'. This common declaration clearly states why the Working Group was established, which results are expected and which activities are undertaken to achieve these results (an operational programme). Within the boundaries of its relatively modest objectives the Working Group has produced considerable output during the last 10 years. The second criterion, co-operation effectiveness, is more problematic. Although there are increasing cross border (flood) communications, improvements in risk analysis and contributions to disaster management, it is impossible to establish the 'problem solving'-influence on the water system of the River Rhine. In regard to stakeholder satisfaction, without exception respondents shared the conclusion that the Working Group is a successful example of cross border cooperation (Verwijmeren and Wiering 2007, p. 97).

\subsection{Policy Arrangements Framework}

\subsubsection{Actors and Coalitions}

As regards the actors' dimension, the policy arrangements in the Netherlands and North Rhine-Westphalia are strikingly similar. In both countries (almost) all actors are government organisations with an interest in flood protection. The division of tasks and resources between these actors is also similar. At both sides actors are included that are involved in policy formulation, that are responsible for policy implementation and that provide for knowledge of the water system. These similarities make it easy for actors to find a cross-border counterpart with whom they can identify. Moreover, it appears important that all actors have a regional background. According to several respondents, regional (policy) actors have a greater sense of urgency of problems in the area and more local knowledge than national state actors. Second, the Working Group consists of civil servants and researchers; politicians are not closely involved. Some respondents feel that they would have been excessively pressured into getting results if politicians were involved.

\subsubsection{Resources}

From the perspective of the interests of North Rhine-Westphalia (as the upstream country) co-operation with the Dutch is not very obvious, although flood measures taken in The Netherlands may affect part of the water system in Germany. But cooperation makes more sense if we look at the available resources. The availability of Dutch knowledge especially, might improve the position of North Rhine-Westphalia 
vis-à-vis other German states. Working on water safety on a project basis (EUprojects mostly) is attractive to regional partners in water management and environmental policy.

\subsubsection{Rules of the Game}

Looking at the rules of the game, the picture is mixed. At the 'micro' level of the Working Group itself, the preference for discussing technical issues makes cooperation easier. "It is more likely that agreement is reached about technical issues than about issues concerning day-to-day policies," to quote one respondent. On the other hand, on the 'macro' level, existing legal differences between the German and Dutch policy arrangements complicate matters. Respondents especially point out the differences in procedures in spatial planning-legislation and at the fact that expropriation is much more difficult in Germany than in the Netherlands. These differences might obstruct the shift towards joint policy and implementation projects (as in the Dinkel case).

\subsubsection{Discourses}

In the discourse dimension, finally, two aspects stand out. First, the substantial water policy discourse of The Netherlands and NRW is similar: to create more space for the rivers. Next to this substantial flood management discourse, there is another discursive element: a story line of transboundary co-operation, which is apparent in North Rhine Westphalia. North Rhine-Westphalia is itself largely dependent on measures taken in upstream German states. As a result, it is greatly in the interest of North Rhine-Westphalia to stress the storyline (or discourse) of 'solidarity between people upstream and downstream'. The consequence of stressing this storyline is that co-operation with actors in the area downstream of North Rhine-Westphalia, i.e. actors in the Netherlands, also becomes important and in a sense even inevitable.

Finally, it is important to stress the wider environment in which the Working Group developed. As many respondents stress, the Working Group did not have to start from scratch. They point particularly at the experiences with cross border cooperation within the International Commission for Protection of the Rhine (ICPR). And they expect that the future European Flooding Directive might be an additional incentive for cross border co-operation.

In conclusion, the Dutch and German policy arrangements are fairly similar and the urgency of the flooding problem is felt in both countries. There is access to resources (especially in the Netherlands) and the parties involved are mainly regional and operate on similar levels. Both countries also feel they can benefit from the exchange of knowledge and they (feel that they) are mutually dependent for a solution of the problem.

\section{Case Comparison}

One of the aims of this article was to illustrate the discrepancy between the (European) ideal of transboundary river basin management and the harsh realities of actual cross border co-operation in regional settings. To explain cross border co-operation, the conditions that lead to co-operation formation, co-operation effectiveness and 
stakeholder satisfaction were identified with the help of a short overview of literature and an analytical framework to compare three cases at the Dutch-German border. The most important findings from the PAA-analysis are summarised in Table 1.

Table 1 Supportive and non-supportive factors for cross-border co-operation

\begin{tabular}{|c|c|c|c|}
\hline Dimensions $\backslash$ cases & Dinkel, river restoration & $\begin{array}{l}\text { Vecht, EU-water } \\
\text { Framework directive }\end{array}$ & Rhine, flooding \\
\hline $\begin{array}{l}\text { General cross } \\
\text { border } \\
\text { dependencies }\end{array}$ & $\begin{array}{l}\text { NL: low } \\
\text { D: low } \\
-\end{array}$ & $\begin{array}{l}\text { NL: high } \\
\text { D: moderate } \\
+\end{array}$ & $\begin{array}{l}\text { NL: high } \\
\text { D: moderate } \\
+\end{array}$ \\
\hline \multirow[t]{2}{*}{$\begin{array}{l}\text { Actors and } \\
\text { coalitions }\end{array}$} & $\begin{array}{l}\text { Similar cross border } \\
\text { counterparts; regional } \\
\text { policy field; administrative } \\
\text { organisations 'fit' }\end{array}$ & $\begin{array}{l}\text { Similar cross border } \\
\text { counterparts, but } \\
\text { differences in policy } \\
\text { or administrative } \\
\text { styles: in D separation } \\
\text { between policy } \\
\text { formulation and } \\
\text { implementation is } \\
\text { strong, while in the } \\
\text { NL it is weak }\end{array}$ & $\begin{array}{l}\text { Similar cross border } \\
\text { counterparts, regional } \\
\text { representatives, } \\
\text { but with national } \\
\text { 'mandates', focus on } \\
\text { technical exchange }\end{array}$ \\
\hline & ++ & - & + \\
\hline Resources & $\begin{array}{l}\text { Interchange of knowledge } \\
\text { resources } \\
\text { Sufficient budgets } \\
+\end{array}$ & $\begin{array}{l}\text { Interchange of } \\
\text { knowledge resources } \\
\text { Sufficient budgets } \\
+\end{array}$ & $\begin{array}{l}\text { Interchange of } \\
\text { knowledge resources } \\
\text { Sufficient budgets } \\
+\end{array}$ \\
\hline Rules of the game & $\begin{array}{l}\text { Project rules clearly } \\
\text { structured } \\
\text { In planning, no obstacles, } \\
\text { but in implementation, yes } \\
+/-\end{array}$ & $\begin{array}{l}\text { Germany: hierarchy; } \\
\text { formalisations; NL: } \\
\text { informal, pragmatic }\end{array}$ & $\begin{array}{l}\text { Small but clear } \\
\text { mandate; Differences } \\
\text { in spatial policies } \\
\text { might become } \\
\text { problem in the future } \\
+\end{array}$ \\
\hline Discourses & $\begin{array}{l}\text { Similar/room for the river } \\
\text { \& ecology }\end{array}$ & $\begin{array}{l}\text { Different ideas on } \\
\text { sources of pollution, } \\
\text { sometimes blaming } \\
\text { each other }\end{array}$ & $\begin{array}{l}\text { Similar/room for the } \\
\text { river }- \text { discourse }+ \\
\text { solidarity }- \text { discourse } \\
\text { of co-operation }\end{array}$ \\
\hline \multirow[t]{2}{*}{$\begin{array}{l}\text { National policies } \\
\text { stimulating? }\end{array}$} & $\begin{array}{l}++ \\
\text { No urgency }\end{array}$ & $\begin{array}{l}- \\
\text { Gradually stimulating } \\
\text { through EU } \\
\text { implementation }\end{array}$ & $\begin{array}{l}++ \\
\text { Sense of urgency, } \\
\text { stimulating cross } \\
\text { border flood policies }\end{array}$ \\
\hline & - & + & + \\
\hline \multirow[t]{2}{*}{$\begin{array}{l}\text { Other contextual } \\
\text { features? }\end{array}$} & $\begin{array}{l}\text { Basic idea of river basin } \\
\& \text { approach and goals later } \\
\text { became integral part of the } \\
\text { WFD as of } 2000\end{array}$ & $\begin{array}{l}\text { WFD procedural } \\
\text { context }\end{array}$ & $\begin{array}{l}\text { Builds upon } \\
\text { experiences in Rhine } \\
\text { co-operation }\end{array}$ \\
\hline & + & + & + \\
\hline $\begin{array}{l}\text { General picture } \\
\text { of cross border } \\
\text { co-operation }\end{array}$ & $\begin{array}{l}\text { Succesful in planning stage, } \\
\text { but not succesful in } \\
\text { implementation stage }\end{array}$ & Moderately succesful & $\begin{array}{l}\text { Succesful in output, } \\
\text { effectivity and } \\
\text { stakeholder } \\
\text { satisfaction; limited } \\
\text { ambitions }\end{array}$ \\
\hline
\end{tabular}


What are the differences and similarities in these three cases at the DutchGerman border? As was explained in Section 4, the cases are similar in regard to the general water policies and cultural features of Germany and The Netherlands. Moreover, all cases have an upstream-downstream problem structure, although this can work out differently in the cases. In the Dinkel Planning-case co-operation was only partially a success: although the planning was successful and promising, it got stuck in the phase of policy implementation. There was co-operation formation and output, but no adoption of policies, thus co-operation effectiveness was limited to making a plan, and results were not satisfactory for stakeholders in the end. In the case of the Vecht (Water Framework Directive) the co-operation formation was very limited with regard to 'institutional sediments', but co-operation can be considered effective within the bounds of the step-by-step procedural process of the WFD. The involved stakeholders were satisfied with the results, although processes were delayed. In the case of the Dutch-German Working Group on High Water) in terms of formation (considerable output, continuing co-operation), effectiveness (using this output to influence policy processes) and with a high degree of stakeholders' satisfaction, the co-operation can be considered successful.

Although none of these cases where categorized as 'failures' and all were at least partly satisfying, the results of the Dinkel planning were disappointing compared to the other two. The characteristics of the cases are summarised in Table 1 and valued variables positive $(+=$ supportive or encouraging) or negative $(-=$ non-supportive or discouraging) for cross border co-operation. Why the Dinkel planning was not brought any further (at that stage), can be related to a low urgency for national authorities and low interdependencies that came with the topic of regional river restoration. But, as already was stated, the initiative had no explicit ambitions to actually implement the planning. Would the Dinkel Planning have been directed at actual implementation, it would probably have been arranged otherwise or, another round of decision making had become necessary; e.g. it would have been necessary to make stronger links to formal decision making procedures in Germany and The Netherlands ('rules'), the arrangement would have included relevant politicians and policy fields in an earlier stage ('actors and resources') and it would have been important to convince them of the value of transboundary planning (transboundary 'discourse'). The planning would have been more concerned with realizing river restoration in a (difficult) agricultural setting, with the problem of expropriation measures, with special planning consequences, etc. Other features of the Dinkel case though, such as the domestic river management discourses and the availibility of resources where not considered real obstacles for further implementation.

Given the Dutch-German relationships ('relatively integrated'), the obligatory nature of the WFD procedures and-on top of that - the integrated river basin approach of the WFD, one can wonder why in the Vecht case co-operation was lingering? This is explained by another feature of policy arrangements and that is the domestic policy organization and policy style. There is strong separation between policy formulation and policy implementation in Germany (i.e. North Rhine-Westphalia and Lower Saxony), while Dutch policy actors are involved in both and pragmatically switch between the two.

In the Rhine case we found strong similarities in the issue of flooding management and in the way the cross border initiative was designed: an attuned constellation of actors, a similar division of tasks between them, a similar discourse on flooding 
management and, perhaps most important of all, a 'solidarity' discourse towards cooperation.

\section{Conclusions and Discussion}

This article adressed questions regarding the barriers and obstacles, but also the incentives of regional cross border co-operation. Our analysis on the Dutch-German border puts forward that, within relatively similar politico-cultural landscapes, cooperation still can differ along the policy issue at hand and the urgency and interests that come along with characteristics of these issues. The regional policy arrangements regarding flooding issues in the Rhine river basin showed strong similarities across the border, but in water quality management the existing differences in institutional structures in Germany and The Netherlands also delayed co-operation. For river restoration was concluded that it suffered from a lack of urgency of co-operation and the project was not tailored to the implementation phase.

When comparing the findings of the literature review with our case studies, the following conditions of, or factors that support, cross borders co-operation, can be distinguished (for a more detailed overview see Verwijmeren and Wiering 2007, 170-171).

Actors:

- Small number of actors

- Actors with similar mindsets

- Actors with similar responsibilities (regional management)

- Involvement of all relevant stakeholders from the beginning

Resources:

- Availability of sufficient financial resources

- Availability of sufficient knowledge

- Willingness to redistribute resources or to achieve issue linkage

Rules of the game:

- Sufficient mandate to make joint policies

- Commitments that are binding, clear, transparant and feasible

- Comparable rules of the game in all countries involved

- Supra-national (European) legislative framework(s)

Discourse:

- Existence of a feeling of urgency

- Existence of a feeling of solidarity

- Focus on issues that are not polically sensitive

- Comparable discourse in all countries involved

Some of the (many) factors of the literature overview can now be highlighted and some are not yet mentioned in previous literature. First, 'problem structure' and related interdependencies still are crucial for a long term impact of co-operation; there must be a (lingering) 'sense of urgency' of co-operation, in order to get policy plans processed in measures on both sides of the border. Second, both substantial 
discourses (e.g. room for the river) and co-operation discourses are important to reach succesfull initiatives. Discourses can change the sense of urgency and the felt interdependencies. Especially in the Rhine river basin the solidarity discourse of the upstream with the downstream country can not easily be overestimated. Finally, we want to put emphasis on the policy cycle in two different ways. The Vecht-case on the WFD pointed at differences in the administrative styles between countries. In this case was concluded that the Dutch combine policy formulation and policy implementation pragmatically, while in Germany these phases are stricly separated. This also relates to differences in the role of experts and expertise. In the Dinkel planning another aspect of the policy cycle was relevant: the planning process was succesful, but the implementation was not. The Dinkel case proved that making transboundary plans is perfectly possible, but implementing them causes many difficulties and asks for new rounds of policy making, with at least new actors, new resources and new rules. New rounds of decision making in the direction of implementing measures on both sides of the border (usually with high expectations of integration) will be also be confronted with a new set of conditions for succesfull co-ooperation.

Our findings on the policy cycle and the difficulties of co-operation in actual implementation suggest the idea of an 'invisible wall' between cross border planning and cross border implementation. In fact, the cases that were modest, with low but clear ambitions of integration, were most successful. This, in fact, sets limits to the ambitions of cross border co-operation. The higher the initiatives' ambition and the further down the difficult road of cross border implementation, the more integrated policy arrangements will have to become and the more complex cross border cooperation is.

Acknowledgements We would like to thank the EU-interregional program of Change on Borders and the involved regions for financing the underlying project of Rivercross (Verwijmeren and Wiering 2007).

\section{References}

Arts B, Leroy P (2006) Institutional dynamics in environmental governance. Springer, Berlin

Barrow CJ (1998) River basin development planning and management: a critical review. World Dev 26(1):171-186

Bernauer T (2002) Explaining succes and failure in international river management. Aquat Sci 64:119

Bezirksregierung Münster (1999) Gewässerauenprogramm NRW Projekt BerkelBerkelauenkonzept, $117 \mathrm{pp}$

Bezirksregierung Münster and Waterschap Regge en Dinkel (2003) Grenzüberschreitende Dinkelplanung_Grensoverschrijdende Dinkelplanning, Münster, 41 pp

Blatter J (2001) Lessons from lake constance: ideas, institutions, and advocacy coalitions. In: Blatter J, Ingram H (eds) Reflections on water, new approaches to transboundary conflicts and cooperation. MIT, Cambridge

Bressers H, Kuks S (2004) Integrated governance and water basin management: conditions for regime change and sustainability. Kluwer Academic, Dordrecht

Crabbe A (2008) Integraal waterbeleid in Vlaanderen: van fluide naar solide. Dissertation, Universiteit Antwerpen (dissertation in Dutch)

Darschnik S, Engelberg K et al (1992) Das Ems-Auen-Schutzkonzept-Von der Erarbeitung einer Bewertungsgrundlage bis zur Umsetzung in Maßnahmenkonzepte zur ökologischen Verbesserung eines Tieflandflusses und seiner Auen. In: Friedrich G, Lacombe J (eds) 
Limnologie aktuell-Ökologische Bewertung von Fließgewässern. Gustav Fischer, Stuttgart, pp 175-204

Dieperink C (1999) From open sewer to salmon run: lessons from the Rhine water quality regime. Water Policy 2/5:471-485

Dieperink C (2000) Succesful international co-operation in the Rhine catment area. Water Int 25/3:347-355

Dupont C (1993) Switzerland, France, Germany, The Netherlands. The Rhine. In: Faure GO, Rubin JZ (eds) Culture and negotiation. Sage, London

Durth R (1996) European experience in the solution of cross-border environmental problems. Intereconomics 31:62-67

Feld CK, Locker-Grutjen O (2007) River restoration in the IJssel catchment. In: Verwijmeren J, Wiering M (eds) Many rivers to cross - cross border co-operation in river management. Eburon, Delft, pp 49-70

Haas PM (1990) Saving the Mediterranean: the politics of international environmental co-operation. Columbia University Press, New York

Jaspers F (2003) Institutional arrangements for integrated river basin management. Water Policy 5:77-90

Jones T, Phillips B, Williams C, Pittock J, Davis T (eds) (2003) Conserving rivers: lessons from WWF's work for integrated river basin management. WWF Switzerland, Gland

Kahler M, Aaron HJ, Keohane RO (1995) International institutions and the political economy of integration. Brookings Institution, Washington

Kaika M (2003) The water framework directive: a new directive for changing social, political and economic european framework. Eur Plan Stud 11:299-316

Keohane RO, Nye JS (1989) Power and interdependence. Longman, New York

Kuks SMM (2004) Water governance and institutional change. Dissertation, Universiteit Twente (Netherlands)

Lammersen R (2004) Grensoverschrijdende effecten van extreem hoogwater op de Niederrhein. MUNLV NRW/Provincie Gelderland, Düsseldorf-Arnhem

Le Marquand DG (1977) International rivers: the politics of co-operation. University of British Columbia, Westwater Research Centre, Vancouver

Lindemann S (2006) Water regime formation in Europe. A research framework with lessons from the Rhine and Elbe river basins. Forschungsstelle für Umweltpolitik, Berlin

Linnerooth J (1990) The Danube River basin-negotiating settlements to transboundary environmental issues. Nat Resour J 30:629-660

List M (1990) Cleaning up the Baltic: a case study in East-West environmental co-operation. In: Rittberger V (ed) International regimes in east-west politics. Pinter, London

Lulofs KRD, Coenen FHJM (2007) Cross Border co-operation on water quality in the Vecht river basin. In: Verwijmeren J, Wiering M (eds) Many rivers to cross, cross border co-operation in river management. Eburon, Delft, pp 71-93

Ma J, Hipel K, De M, Cai J (2008) Transboundary water policies: assessment, comparison and enhancement. Water Resour Manag 22(8):1069-1087

Marty F (2001) Managing international rivers: problems, politics and institutions. University of Zurich, Bern

Meijerink SV (1998) Conflict and co-operation on the Scheldt River Basin: a case study of decision making on international Scheldt issues between 1967 and 1997. Dissertation Delft University, Kluwer Academic, Dordrecht

Meijerink SV (2008) Explaining continuity and change in international policies: issue linkage, venue change, and learning on policies for the river Scheldt estuary: 1967-2005. Environ Plann A 40(4):848-866

Meijerink S, Wiering M (2009) River basin management in Europe: the 'uploading and downloading' of a new policy discourse. In: Arts B, Lagendijk A, van Houtum H (eds) The disoriented state: shifts in governmentality, territoriality and governance [series: Environment \& policy, vol 49]. Springer, Dordrecht

Mostert E (1998) River basin management in the European Union. Eur Water Manag 1:26-35

Saetevik S (1988) Environmental co-operation between the North Sea states: success or failure? Belhaven, London

Skjaerseth JB (2000) North Sea co-operation: linking international and domestic pollution control. Manchester University Press, New York

Staatliches Umweltamt Münster (1999) Gewässerauenprogramm Ems-Ems-Auen-Schutzkonzept. Berichte und Informationen, Band 4: 37 pp. + Annex. Staatliches Umweltamt, Münster 
Staatliches Umweltamt Münster (2006) Gewässerauenprogramm Ems-Ems-Auen-Schutzkonzept 3 : 47 pp. Staatliches Umweltamt, Münster

Tucker Gilman R, Abell RA, Williams CE (2004) How can conservation biology inform the practice of Integrated River Basin Management? Int J River Basin Man 2(2):1-14

Van der Keur P, Henriksen H, Refsgaard J, Brugnach M, Pahl-Wostl C, Dewulf A, Buiteveld H (2008) Identification of major sources of uncertainty in current IWRM practice. Illustrated for the Rhine Basin. Water Resour Manag 22(11):1677-1708

Van Stokkom HTC, Smits AJM, Leuven RSEW (2005) Flood defense in The Netherlands: a new era, a new approach. Water Int 30:76-87

Van Tatenhove J, Arts B, Leroy P (2000) Political modernization and the environment. The renewal of environmental policy arrangements. Kluwer Academic, Dordrecht

Verwijmeren J, Wiering M (eds) (2007) Many rivers to cross. Cross border co-operation in river management. Eburon Academic, Delft

Watson N (2004) Integrated river basin management: a case for collaboration. Int J River Basin Man 2:243-257

Wiering MA, Arts BJM (2006) Discursive shifts in dutch river management: 'deep' institutional change or adaptation strategy? Hydrobiologica 565:327-338

Wiering MA, Crabbé A (2006) The institutional dynamics of water management in the low countries. In: Arts B, Leroy P (eds) Institutional dynamics in environmental governance. Springer, Berlin

Young OR (1999) The effectiveness of international environmental regimes: causal connections and behavioral mechanisms. MIT, Cambridge 